\title{
Topology of economic systems
}

\author{
Mark Klinedinst ${ }^{1}$, Charles Rock ${ }^{2}$ \\ (1. University of Southern Mississippi, Hattiesburg 39529, USA; 2. Rollins College, FL 32789, USA)
}

\begin{abstract}
An economic topology can have many uses to the academician, student and practitioner. Refining a topology of economic systems helps to bring together seemingly disparate characteristics and to point out potential long run trends. The progression of economic systems over time and also brief explanations of each system are given. We argue that most modern economic systems have some remnants of earlier forms, that is, most economies today are some mixture of what might be considered pure systems. Measurable characteristics to identify a particular system are developed that allows progress to or from a particular classification to be charted for individual countries.
\end{abstract}

Key words: economic systems; capitalism; socialism; transition; labor-managed

\section{Introduction}

An economic topology can have many uses to the academician, practitioner and student. Refining a topology of economic systems helps to bring together seemingly disparate characteristics and point out potential long run trends that may be useful in refining theory and the data gathered to analyze new theories. Practitioners when advising a policy organization (e.g., government, NGO or company) would be aware of underlying trends that help to shape the current situation. Teaching economics at the introductory level, and in upper level classes, creates a need to distinguish for students the different economic forms that exist presently, have in the past, or might conceivably be developed. We have found it useful to display a graphic to describe the progression of economic systems over time and also as brief explanations of each system are described the students become to realize that most modern economic systems have some remnants of earlier forms, that is most economies today are some mixture of what might be considered pure systems. A number of countries are in what has been called "transition." The dramatic reorganization of countries that were part of the former Soviet Bloc stand out in many people's minds as some of the more noteworthy of the last few years. The attempt to create a "third way" with a labor-managed economy can also be viewed critically within this framework. Although a topology of such a large topic is bound to leave out a number of important nuances, a discussion of chronological system transformations is likely to lead to less ideologically created policy and to greater scientific scrutiny. In this paper we attempt to develop measures that gage the movement of countries along this landscape in order that long-term patterns may be discerned and to show the common features that form any particular system.

At least since the enlightenment, historians and social thinkers have had a proclivity for making typologies so that they can talk about periods in history or about possible future histories. Economists are no different. Most of Adam Smith's “The Wealth of Nations” was devoted to the history of civilizations moving from primitive through

Mark Klinedinst, Ph.D., professor of economics, University of Southern Mississippi; research fields: economic theory, comparative economics.

Charles Rock, Ph.D., professor of economics, Rollins College; research fields: economic theory and comparative economics. 
the existing "mercantile” arrangements of 1776. As to the future, Smith argued that many features of his time's economic system could be disposed of by taking advantage of self-interested behavior in competitive markets with competitive prices acting as the main allocation mechanism.

Marx and many followers endorsed a dialectical historicism that saw the past mainly through the focus of understanding of how "capitalism" came into being. What preceded it was defined as "feudalism" which somehow hop-scotched across Smith's mercantile period (renamed as only a transition of "merchant capitalism” or some elements of "primitive accumulation") and became transformed into capitalism. As to the future, Marx said many things about the nature of capitalism and its internal contradictions that appeared to foretell an inexorable evolution of his own time's "capitalism" into some kind of "socialist" mode of production, and, finally, once scarcity was abolished through technological development, into some voluntaristic abundance of something his putative followers called "communism." Marx and Smith have been the two major economists behind most of the commonly accepted competing economic systems, but their analysis has been refined by many to help us trace what has actually occurred and what might be feasible.

The Marxian tradition is rich in thinking about historical "stages" or "modes of production." Following the growth (or rebirth) of imperialism in the late 19th century some writers discussed the colonization of Africa and Asia as perhaps a new stage of capitalism (e.g., both early and later variants in the 20th century thought: Lenin, Luxembourg, Samir Amin, Gunder Frank). Likewise for the rise in power of financial relations and markets after WW I; for some thinkers "finance capitalism" (think J. P. Morgan or the stock markets of the 1920s) becomes a new "mode" or at least a change in a mode, as the replacement for the preceding "industrial capitalism" (think Andrew Carnegie). In mid-20th century, as markets become dominated by only a handful of firms, Baran and Sweezy coin "monopoly capitalism" to describe this twist in capitalism which threatens permanency due to the government-business nexus of mutual service, that seemed linked to military procurement desires of the Cold War (1945-1992).

Among more mainstream economists, stages theory of economic evolution is found regularly. In mid-20th century, Joseph Schumpeter saw the rise of the giant corporation and its human bureaucratic human relationships and incentives as the death knell of competitive capitalism's benefits. He believed that without fiercely competitive markets, there would be less "creative destruction" and less dynamism than in the past.

Walt Rostow, one of Kennedy's advisors, came up with a stages theory of economic development in the 1960s. He employed a memorable airplane metaphor for the sequence of stages that the poor, newly-independent countries ought to mimic. If they did copy this model, then they would follow in the footsteps of the USA or the UK or other rich countries. Crudely it seemed to say: Think of all the things you need for the plane (or borrow it), learn all about it, then taxi it, and check it all out, and then take-off in it! Unfortunately many countries bought many of the economic policy parts but the design may have been faulty to begin with (both the plane and the recipe for predictable economic growth for all nations).

So, if we sum it all up, we see people creating typologies of economies (both abstract models and actual groups of countries) for at least three purposes.

(1) As a useful abstraction to get a clear sense of past changes-to spot key separation periods in historical evolution of economies or to see how different places went through similar developments simultaneously, or at different times.

(2) As a means of talking clearly about contemporary economies-grouping can help identify and simplify which features appear related to performance goals (of course, these goals may differ depending on the observer). 
(3) As a means of seeing the present economy or many economies carrying a spotlight on the variables that may bring about change (including regression) or stasis. This has been applied frequently seeking to predict likely or almost inevitable futures.

Typically, the unstated interest of many stage theorists has been in some sort of "progress." This is one of the dominant projects that come to us in the last millennium via ideas of "rebirth" of clever knowledge and about "enlightenment" that allows us to become rational about creating more "progress" and "modernity."

In the early 21st century, we cannot neglect the debates about the foundations and uses of knowledge. The contributions of "post-modernism" question the way ideological biases and real power relationships are embedded in scientific justifications and analysis. Some of this tradition would point to the relativism that all human-created schema are loaded with. Feminists might question the typical lack of gender analysis in these frameworks, especially if they were trying to be historical or contemporary taxonomies, rather than futuristic utopian categories. Other issues often left out of the main categories of economic analysis include, race, environment, ethnicity, and sexuality. We beg that big post-modern question and simply appeal to our likely readership among economists. This paper has limited scope.

The next section of this paper will describe the reasoning behind the topology and give a brief explanation and example of each system. The third section of the paper will explore what are useful data that may be developed from this framework that may lead to better predictions and explanations of current economic events. The fourth section will look at some of this data and the results of actually fitting current countries in this structure. The final section will summarize the policy implications and areas for future research.

\section{Description of the topology}

An economic system is a self-replicating set of relations among people. This system has an internal dynamic that often leads to change, but it is also recognizable in comparison to other systems (Robinson, 1963).

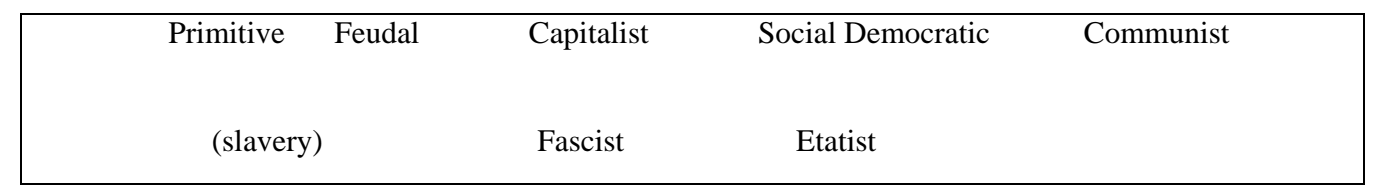

Fig. 1 Topology of economic systems

The top row in Fig. 1 shows the development of economic systems over time. This top row shows what has actually occurred in history. In order to show this progression over time we will use definitions of economic systems that are commonly held by many in this field, but certainly not held with unanimity. The primitive and feudal economic system definitions are the ones that have the least controversy surrounding their definition, and hence will be described fairly briefly.

Primitive economic systems include small hunter-gatherer groups (e.g. clans living in today's Amazon rainforest) and may, in some definitions, include larger organized ancient command systems such as Egypt under the Pharaohs. Ancient systems could be lumped into this category, even though they may contain elements of more modern systems, in the fact that being ancient often meant poorly developed parts of what may be called the institutional infrastructure of a modern economy (e.g., the use of money, political rights, property rights, capital markets, judicial system, and political system).

Feudal economic systems are systems typically built on the hereditary right to power. The rulers in this 
scheme were often responsible for the protection of the nation with the peasants in turn with the obligation to support this warrior-ruling class. A classic example would be the monarchies of Europe up to about two hundred and fifty years ago (e.g., United Kingdom around 1750). Marx's methodology in studying society and its evolution, as Bertell Ollman nicely exposed in his book “Alienation,” was also quite complex—neither simply reductionist (atomistic) nor holistic. Marx’s approaches were both of these and more (Ollman, 1976). What was the most essential aspect of "capitalism" that distinguished it from previous modes of economic activity? Many readers of Marx or, more usually, of his interpreters have claimed that "capitalism" was simply an economic system in which there were only two critical economic classes-those that owned and controlled property, and those that owned nothing except themselves, their labor; The first group hired the second to work for them (and with their property or "capital”) in order to "accumulate capital". There is still a problem if we only use this definition. Looking at the economies supposedly in the "feudal" period, we can see both a propertied and a property-less group; Moreover, many of those with some property tried to get more of it. So maybe the distinction is in the "hiring" issue. Lords abused peasants/serfs but the relationship was different from the "abuse" in the labor markets of capitalism. The absence of an extensive market and the use of hereditary title for political and economic power also set feudalism apart.

Historically capitalism did not come about until after feudalism. The development of the merchant class (bourgeoisie) and the writings of a number of authors, notably Adam Smith, helped create an environment that helped bring about a new economic system. The early years of capitalism (still relatively new in the historical time frame looked at here) were quite different than what most authors would today describe as characteristic of a modern capitalist system. In order to define this more modern version and to help create important distinctions between the economic systems that are commonly seen today, we will develop five points to identify capitalism and other systems. Again, given the broad nature of the subject matter we are looking at, a note of caution is urged here. We are not claiming that the following five points are exhaustive in describing an economic system, but they do capture salient features that can be used to distinguish what has often been claimed to be totally different systems. These five points lie at the heart of an economic system, there are other dimensions that we are not exploring (e.g. international relations and the environment) and some probably not yet discovered.

The first point of distinction in capitalism is the primacy of private property. No longer is the aristocracy, the crown, or the state the sole or primary decision maker for property. The private ownership of property is extensive. This includes the rights to sell and buy property.

The second point of distinction is the use of the market to allocate resources. Market forces in a capitalist system determine the price and quantity of a large number of goods and services, as well as labor power.

The third point is that the government plays a limited role in the economy. The third is related to the second point, but given the growth of the government role in most modern market economies, it is often seen as a useful place for distinguishing economic systems. Most market systems have moved well past their early years, when the ideal was of government playing the limited role of protecting the country, protecting private property and providing a stable background to ensure robust competitive markets.

The fourth point is that there is democracy with more than one major political party. This point is thought to be important to ensure "a level playing field" for competitive markets. Also, even though democracy has often been quite limited in a number of capitalist economies in the past (e.g., in the U.S. where only rich white men could vote, Chile under Pinochet, etc.), the current stress here on democracy comes from the recent historical example of countries with only one political party that have slid into a command economy. 
The fifth and final point that we use to distinguish economic systems is the type of firm structure. In most capitalist economies the traditional firm structure is that of hierarchical command. In many sectors partnerships, cooperatives or employee stock ownership plans are often found, but these often are merely used as incentives and hardly change the control structure in the firm. The number of firms with command structures that are not authoritarian seems to be growing in a number of capitalist countries.

The countries that may typify this type of economic system today would be the U.S., Japan and Canada. This does not mean that there are not diverse structures and initiatives within these countries that deviate from the thumbnail descriptions given above. A major feature that needs emphasis in defining these economic systems, is that these are theoretical snapshots. In the modern world with an increasing pace of change, a country typically does not fall so easily within a category. Indeed, once we have identified the major systems we will argue that many countries are in the process of becoming another system and that they currently have these seeds, as they often have the residue from former systems.

A modern socialist system, or social democratic system, deviates from the capitalist system in a few important characteristics. The use of the term socialist here is in agreement with many authors (Zimbalist, et al., 1989; Horvat, 1982, p. 190), but at variance with the identification of the former Soviet Union as socialist (Djankov, et al., 2003). The definition we use is closer to that of leading socialist parties' use in advanced market economies (Socialist International, 2004), not how dictatorships attempt to define themselves. For example, North Korea calls itself the Democratic People's Republic of Korea and claims to be socialist, North Korea is neither democratic or socialist. The countries that we will identify as socialist are sometimes called welfare capitalist, peoples' capitalist, or market socialist capitalist countries (Lange \& Taylor, 1964).

Private property would still be extensive in a social democratic system. Again similar to the capitalist system, resources would be allocated primarily by a market mechanism. One of the big differences would be the amount of government involvement in a social democratic economy versus a capitalist laissez faire economy. Public education, public highways, social security, unemployment compensation, socialized medicine and active policies to keep unemployment low would be representative of this more active government role. There is typically discussion of semi-autonomous corporate entities that would be necessary at times to provide production and competition. Democratic pluralism as in the modern capitalist economy would also hold true in the social democratic economy. The firm structure is another area that would differentiate the social democratic economy. Most modern social democratic thinking expresses the desire to push democracy from the rarefied air of national politics, and sometimes petty decision making of local political authorities, directly into the workplace. Workplace democracy is the often touted ideal, where there is one-person, one-vote on firm decisions. One of the more celebrated examples of democratic production in a market economy is the Mondragon group of cooperatives (Mondragon, 2008).

The final economic system, communist, is the one pointed to by the Marxian paradigm and other utopian thinkers, but we will argue that in actuality there has never been a communist country yet. Although Marx spent a good deal of time critiquing the short comings of the capitalist system, he did not make such an effort in elaborating a communist system. Most modern versions of communism would place, as would Marx, a central role on the democratic control over the means of production, something that was clearly missing in the former Soviet Bloc and other countries that called themselves communist. Rather than going over each of the five points for a system that has not existed, we will briefly summarize what it might look like. The best guess at a democratic economy based around the principle of "from each according to their ability, to each according to their 
need" might be a more egalitarian version of the social democratic economy with greater worker place democracy (Marx, 1891).

Clearly the countries that call themselves communist have failed to have democracy sustained in the political sphere and often the command structure in the firm is authoritarian as well. These countries we call Etatist economies. They are totalitarian counterparts to the social democratic ideology, the degenerate case of socialism. Their neighbors in Fig. 1 are the fascist regimes that are the degenerate capitalist regimes. Both have strong state regimes that are repressive. Both tend to arise when the state is threatened either by war or a macroeconomic failure such as a depression. Stalin after the civil war in Russia, Hitler after the hyperinflation and stagnation in Germany are prime examples. Fascism like etatism, mirrors the above system in many ways, adding a strong government overlay to a capitalist system.

Slavery is included here as a sub-system. It is a system that has been found in just about every major system. The incidence of slavery as a percent of the population has diminished over time, hence as you move across the top of the topology, but even now there are probably countries that are social democratic in many ways (e.g., Netherlands and Norway) where some form of slavery exists in the form of immigrants in the sex industry or domestic workers that have few rights (Slavery Today, 2004). Fig. 2 includes the examples of each of the systems discussed in this section with the original figure.

\begin{tabular}{|ccccc|}
\hline $\begin{array}{l}\text { Primitive } \\
\text { (Amazon) }\end{array}$ & $\begin{array}{c}\text { Feudal } \\
\text { (U.K. circa 1750) }\end{array}$ & $\begin{array}{c}\text { Capitalist } \\
\text { (U.K. 1850) }\end{array}$ & $\begin{array}{c}\text { Social Democratic } \\
\text { (Sweden 1980) }\end{array}$ & $\begin{array}{c}\text { Communist } \\
\text { (empty set) }\end{array}$ \\
(slavery) & & $\begin{array}{c}\text { Fascist } \\
\text { (Nazi Germany) }\end{array}$ & $\begin{array}{c}\text { Etatist } \\
\text { (Soviet Union) }\end{array}$ & \\
\hline
\end{tabular}

Fig. 2 Topology of economic systems, with examples in parentheses

The topology, as it is designed here, has the advantage over some descriptive methodologies in that it at attempts to be inclusive of all forms. It explicitly shows some of the dramatic impact that the political process has on the economy, as so many authors in the past and recently have pointed out (Hobbes, 1651; Marx, 1891; Hayek, 1960; Becker, 1983; Vanek, Horvat, 1982; Mandel, Buchanan \& Tullock, 1962). The "institutional possibility frontier" could fit inside this scaffolding of systems. The possibilities available between dictatorship and the disorder of a market system may partially lie on the path between the command systems in the lower row and their more democratic counterparts above (Djankov, et al., 2003 for a discussion of this path as taken by recent transition countries).

\section{Uses and predictions}

A topology like the one developed here could have a number of uses. Understanding the types of economies that compete on the world stage, their strengths and weaknesses, might lead us to change policy to avoid the repressive regimes. Realizing that severe stress to what are the commonly found systems that may precipitate a system change would help guide policy to look at warning signals. The degenerate command cases can develop relatively quickly from a previous state, a fact that many newly independent impoverished countries, rushing to grow their economies, tried to take advantage of it. Instead of moving from feudal-capitalist mixed economies to a capitalist economy, many of these countries tried to skip this step and move to the social democratic system. It turns out, as in the case of Russia and Cuba, this was via an Etatist regime. This trade off of the disorder of the market allocation mechanism for the forced investments of the plan, often brought higher per capita GDP at the 
price of a more flexible and dynamic democratic pluralism. The comparison of India and China in 1949 and the route they have followed since would be examples of trying to stay along the top row, versus the forced development under the Etatist regime (path would be an arrow for India across the top, a "U" for China from feudalism-etatism-social democratic). Will a "U" shaped path be a faster path to a modern market economy or will the rigidities and political uncertainty of the transition cause China to go through a tough period of adjustment?

As you move across the top, another prediction is that the change of a new system occurs more quickly over time. We do not believe this is solely due to the blinders of someone observing from their own time, but perhaps due to the development of technological and demographic factors. This quickening of the pace of regime change over time is also cause for some optimism. The harsh conditions that many people live in may be ameliorated as their countries transition to more productive and democratic systems. This same optimism needs to be guarded knowing how quickly command economies may arise and given the growing sophistication of surveillance equipment necessary to keep them in place.

Developing an empirical counter part to Fig. 1 is difficult to accomplish. If an index were created that captures the five characteristics of an economic system we could measure, among other things, warning signals of change or the time it has taken to traverse from one system to another.

There are tremendous problems measuring accurately across time and countries the extensiveness of private property, the market system, government intervention, pluralism, and the degree of authoritarianism in firms. We have looked for such an index, but there is none that we are aware of that captures all these features and has them for a number of countries over time. To create such an index is beyond the scope of this paper. We did try to find data that captures at least some of the dimensions over time. One likely candidate is the "Human Development Index" (HDI).

The HDI captures a number of items that were included in the five points that define and economic system and implicit in development of economies over time. There are three main components to the HDI (United Nations, 2003, p. 341); longevity, literacy rates, and GDP per capita. These are not the five points mentioned earlier, but there should be a strong correlation with movement from left to right across the topology and the HDI. For example, the number of merchants in a capitalist economy is greater than the number of rulers in a feudal economy, hence those with access to education and healthy environments should also be greater. Construction of an index specifically designed for this topology could be attempted, but the use of a commonly referred to index allows easy replication. The development of more sophisticated indices of economic performance has in the last twenty years gained increasing attention (e.g., HDI, environmental development index, etc.). Part of the reason we would suggest is that the goals of more advanced social systems address the interests of a broader group of people, hence the simplistic use of GDP growth will no longer adequately describe development. A plot of the HDI with the GDP per capita should obviously show positive correlation since HDI is a function of the GDP, but interesting outliers might show economies with less democracy, feudal or fascist in particular, being below the trend. Etatist regimes would likely be on trend without any correction for pluralism. In order to correct for the lack of democracy (criterion number four) we use the index from the Freedom House (2004) and Amnesty International (2004). Other indices showing the lack of political and civil liberties could be used, but these we chosen for our initial investigations given how widely they are known.

\section{Empirical results}


The summary statistics for the data used are reported in Table 1. The Human Development Index used here for 175 countries in 2001 had a mean of 0.698 . The top five countries were Norway, Iceland, Sweden, Australia and the Netherlands (with HDI's respectively of 0.944, 0.942, 0.941, 0.939, 0.938). The bottom five countries were Mali, Burundi, Burkina Faso, Niger and Sierra Leone (with HDI’s respectively of 0.337, 0.337, 0.330, 0.292, 0.275). The top and bottom countries by HDI reported above are not too surprising, what does start to illustrate the trend across the topology is if the HDI is plotted against per capita GDP as in Fig. 3. The trend as one would expect is that over time as GDP per capita goes up, the HDI would go up. The countries clearly below the trend are where questions arise. Why are these countries (e.g., United Arab Emirates, Oman, South Africa, Qatar, and Saudi Arabia) having lower development scores even with a relatively high per capita GDP?

Table 1 Summary statistics

\begin{tabular}{|c|c|c|c|c|}
\hline Variable & Mean (Std. Dev.) & Min & Max & Number \\
\hline $\begin{array}{l}\text { Human Development Index } \\
2001(\mathrm{HDI})^{1}\end{array}$ & $0.698(0.177)$ & 0.275 & 0.944 & 175 countries \\
\hline $\begin{array}{l}\text { Bottom } 40 \text { percent share of } \\
\left.\text { income }^{2} \text { (1947 to } 1995\right)\end{array}$ & $0.185(0.046)$ & 0.053 & 0.284 & 621 observations \\
\hline $\begin{array}{l}\text { Bottom } 80 \text { percent share of } \\
\text { income (1947 to } 1995)\end{array}$ & $0.572(0.077)$ & 0.316 & 0.729 & 621 observations \\
\hline Gini coefficient (1947 to 1995) & $35.6(9.30)$ & 17.8 & 63.2 & 621 observations \\
\hline Political rights $^{3}$ (1972-2003) & $2.96(2.11)$ & 1 & 7 & 610 observations \\
\hline Civil liberties (1972-2003) & $3.06(1.96)$ & 1 & 7 & 610 observations \\
\hline FreedomLack ${ }^{4}$ (1972-2003) & $0.430(0.285)$ & 0.143 & 1 & 610 observations \\
\hline
\end{tabular}

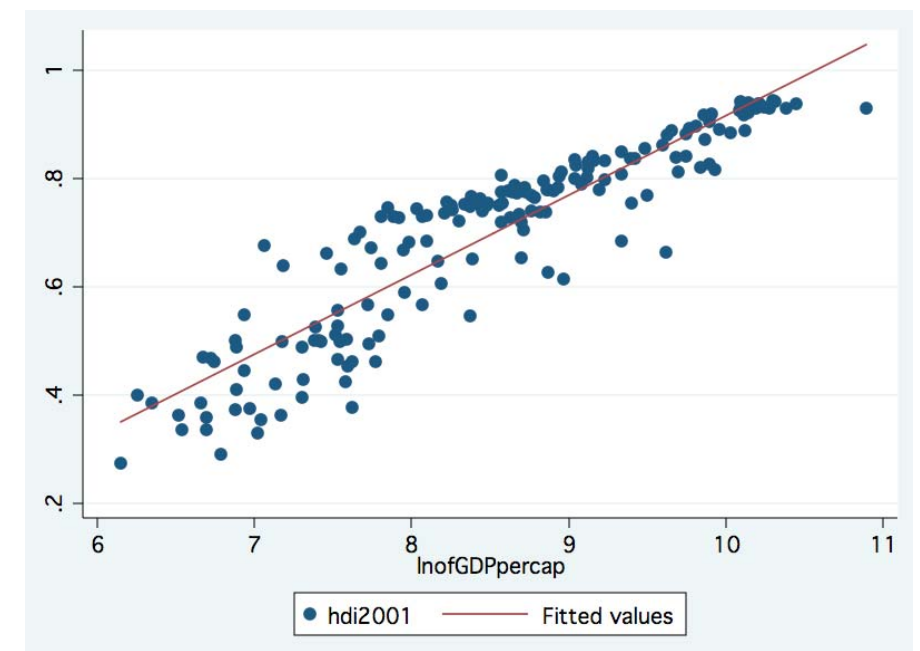

Fig. 3 Human Development Index (HDI) 2001 and per capita GDP Notes: $\mathrm{Y}=-0.554+0.147$ (Inof GDPpercap), $\mathrm{R}^{2}=0.84$.

The percent of income of a country going to the bottom 40 percent and the bottom 80 percent is also reported in Table 1. The top five countries with the highest percent going to the lowest 80 percent of the population in the

\footnotetext{
${ }^{1}$ Human Development Report, 2003.

2 “Acceptable quality” observations from Deininger and Squire data set of the World Bank, 2004.

3 Taken from Freedom House data 2004, 7 is the worst and 1 is the best (http://www.freedomhouse.org/ratings/index.htm).

${ }^{4}$ ((PolitRights/7) + (CivilLib/7))/2.
} 
data set are all either Etatist or former Etatist countries e.g., Bulgaria, Czechoslovakia, Slovak Republic, Hungary, and Poland (respectively with 0.729, 0.688, 0.686, 0.678, and 0.677). The bottom five countries are Brazil, Gabon, Mexico, Honduras, and South Africa (respectively with 0.316, 0.337, 0.339, 0.347, and 0.351). As development proceeds over time across the top of the topology as drawn in Fig. 1 and Fig. 2, we would expect an expansion of opportunity, and hence income, for people outside of the "commanding heights" of the economy. Fig. 4 shows this trend over almost half a century (the figure for the bottom 40 percent not shown here is similar to that of the bottom 80 percent). A clear upward trend is seen here, as might be expected as democracy strengthens. Some countries without democracy, the totalitarian systems of fascism and etatism, would also be relatively high here. The Gini coefficient of income distribution was also used and a similar pattern emerges of this same time period as shown in Fig. 5 (since the Gini goes up as inequality goes up, 100 minus the Gini was used on the vertical axis for comparison to the earlier figures).

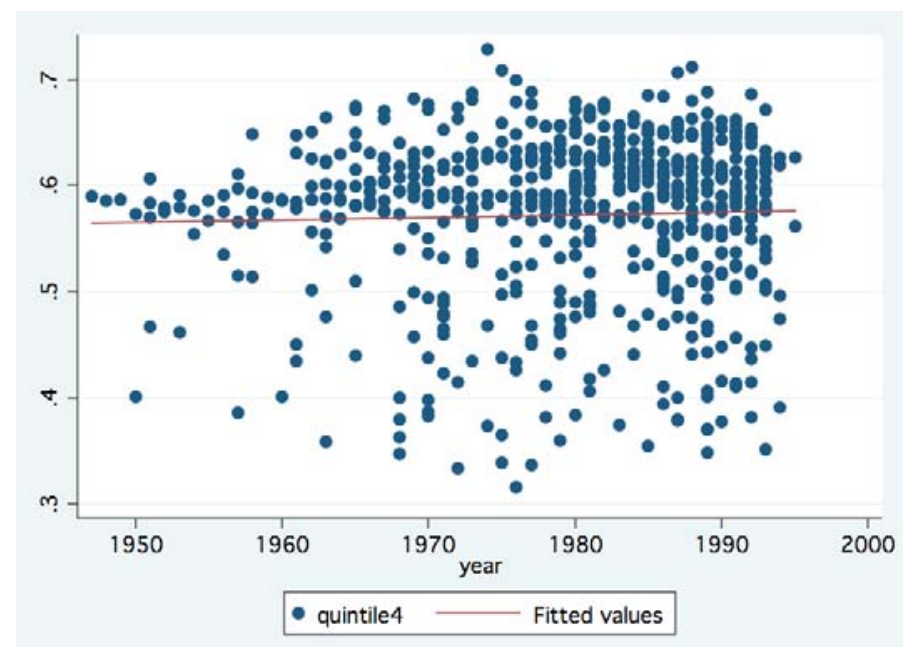

Fig. 4 Bottom $80 \%$ share of income

Notes: $\mathrm{Y}=0.1118983+0.0002327$ (year), $\mathrm{R}^{2}=0.00$.

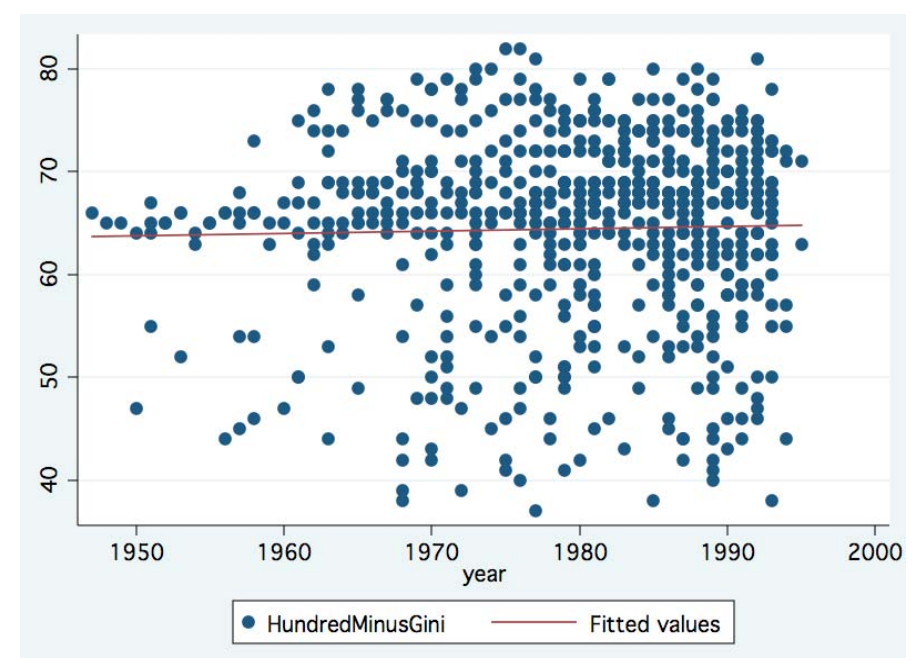

Fig. 5 100-Gini coefficient over time

Notes: $\mathrm{Y}=19.5227+0.0226983$ (year), $\mathrm{R}^{2}=0.00$.

The topology makes the important distinction that pluralism must exist to be classified as an advanced 
economy (capitalist or social democratic) and the above measures do not explicitly capture that facet of countries. To attempt to capture pluralism a number of measures of democracy were looked at (Amnesty International, FreedomHouse, etc.). An advantage of the Freedom House index of political and civil liberties is the length of time and breadth of coverage spans a similar range as the HDI and inequality data. We combine their measures on political and civil liberties to create a variable called FreedomLack (available for different years for countries in the period from 1972-2003). This variable has a mean 0.43 with a minimum 0.143 and a maximum of 1 . The higher the number the lower the freedom. The freest countries by this measure are Sweden, New Zealand, Australia, United Kingdom and Costa Rica (all at the minimum of 0.143 as were others). The worst in terms of freedom (a score of 1 here) were all Etatist period countries Bulgaria, China, Romania, Czechoslovakia, and the Soviet Union. When this FreedomLack variable is subtracted from the data showing expansion of opportunity (HDI, Gini, or quintile data on income) a clear dual development path is noted over time (see Fig. 6 and Fig. 7 show the plot for the quintile data) ${ }^{5}$. These graphs use widely available data to replicate the topology outlined in Fig. 1. The economic and political transition of a number of countries the last 18 years is also seen in the increase in data points moving towards the top right.
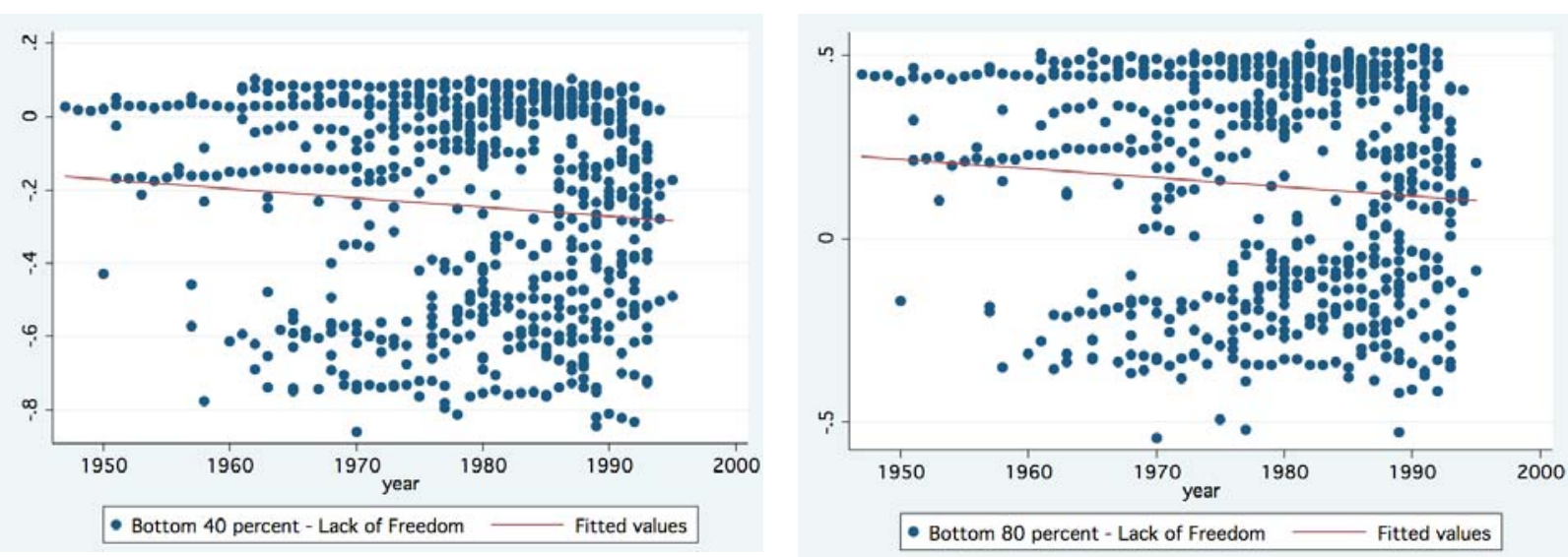

Fig. 6 Bottom 80 and 40 income share minus freedomlack plotted over 1945-1995 Notes: $\mathrm{Y}=5.045068-0.0024765$ (year), $\mathrm{R}^{2}=0.01 ; \mathrm{Y}=4.749655-0.0025234$ (year), $\mathrm{R}^{2}=0.01$.
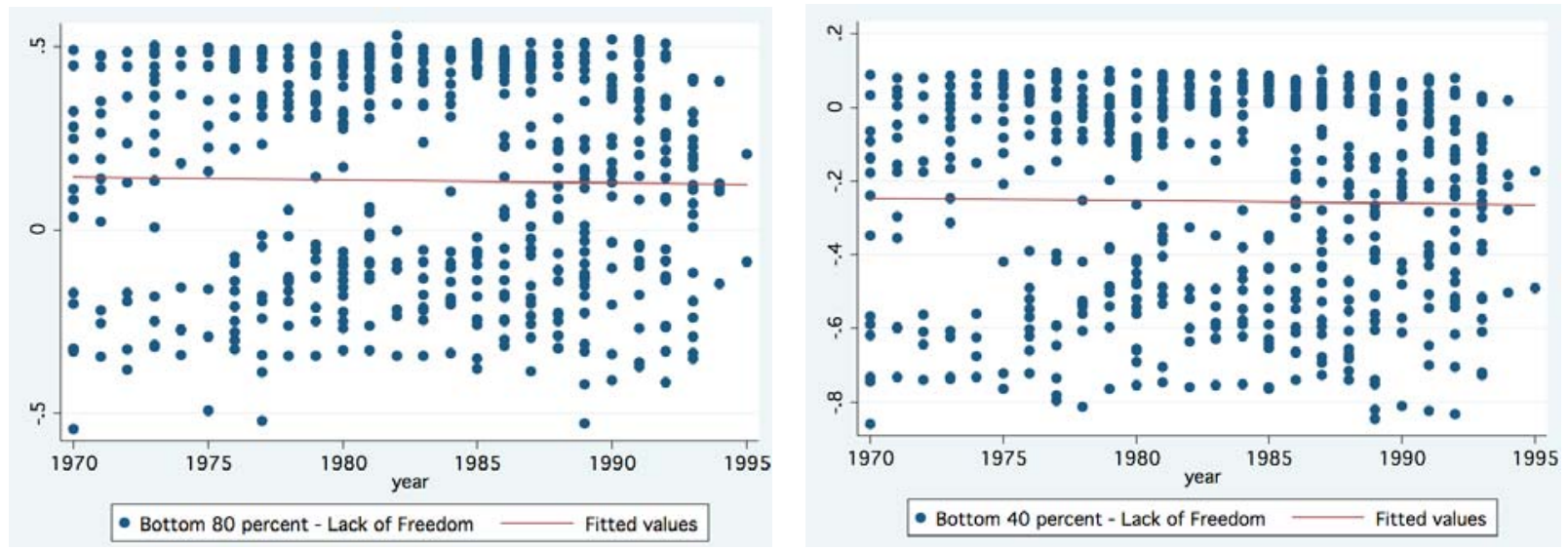

Fig. 7 Bottom 80 and 40 income share minus freedomlack plotted over 1972-1995

$\mathrm{Y}=1.645031-0.0007624$ (year), $\mathrm{R}^{2}=0.00 ; \mathrm{Y}=1.155422-0.0007115$ (year), $\mathrm{R}^{2}=0.00$.

\footnotetext{
${ }^{5}$ Note that the freedom data reported in Table 1 only goes back to 1972, hence the data points before 1972 reported in Fig. 6 use the 1972 freedom numbers for the earlier years. Fig. 7 uses data from 1972-1995 only.
} 
Fig. 8 breaks down the movement of the top countries (developed capitalist and social democratic countries) from the less developed countries (countries with more fascist or Etatist elements) and fits two curves for their movements. ${ }^{6}$ The fit is visually better (and higher $\mathrm{R}^{2}$ as well) when the sample is divided. The developed countries saw a peak around 1981, with regression since then, while the less developed countries saw a bottom in 1974 with an increase after. These two fitted lines indicate tendencies toward convergence for the two groups. This finding is consistent with the increasing income inequality in some developed countries and the spread of democratic institutions in developing countries.

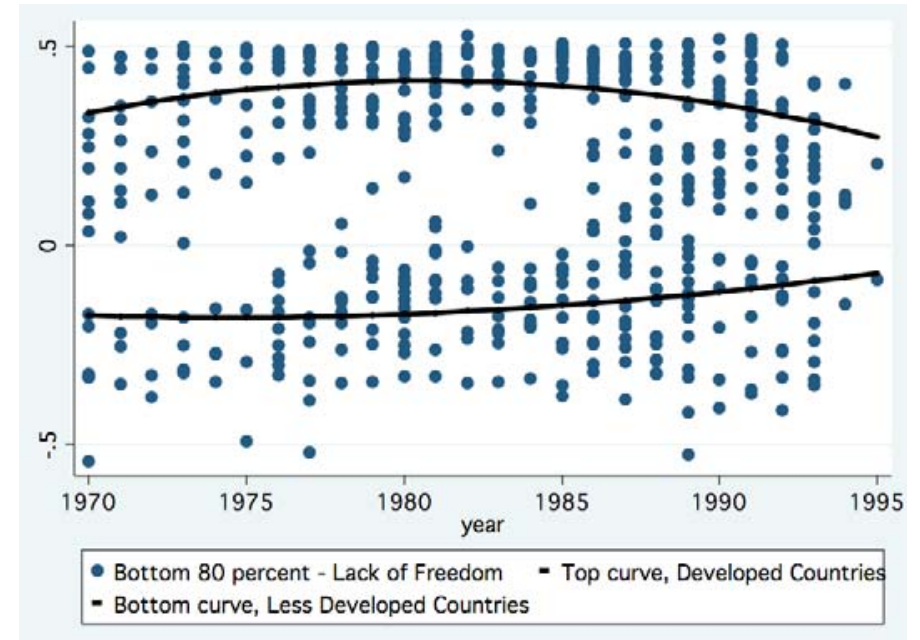

Fig. 8 Bottom 80 income share minus freedomlack plotted over 1972-1995

Notes: Developed Countries $\mathrm{Y}=-2713.656+2.74045$ (year) -0.0006918 (year) ${ }^{2}, \mathrm{R}^{2}=0.10$;

Less Developed Countries $\mathrm{Y}=1030.558-1.044$ (year) +0.0002644 (year) $^{2}, \mathrm{R}^{2}=0.04$.

\section{Summary and policy implications}

The topology developed here has a number of practical and theoretical uses. As a guide to students and economic discourse the arrangement diagrammatically of various economic systems that have existed and those that have been proposed allows for comparison for related systems while also highlighting historical trends. The determination of when a system is "finished" its transition could also be marked by referencing the five stylized facts about each economic system (Eicher, 2004; Svejnar, 2002). Further research on the internal dynamics of each system and what propels the movement from one system to another may be useful. Certainly among all species, humans might be considered close to the hyperadaptive end in comparison. Ultimately the desire for freedom and a sociable community (fraternity, love, etc.) that many have stated as an innate human striving would hopefully win the day over our adaptability to disutopian futures.

Fleshing out the key determinants of each system would help in tracking the path economies are taking and likely to take. The measurement of the economy has gotten more sophisticated over time in this attempt to track our progress, from simple measures of GDP to the HDI and new measures that incorporate gender and environmental issues. The topology suggested here implies that these measures should also include some measure of pluralism and internal firm structure as well.

\footnotetext{
${ }^{6}$ The data were divided by fitting a quadratic function separately for those countries above and below the mean (0.143) for the variable "bottom 80 of income percent - lack of freedom."
} 
The empirical work here attempted to discern the topology suggested from data that was widely available. Although not matching precisely the five key elements suggested earlier the data used here capture important characteristics of each system. Interestingly the data replicate visually many of the predictions of the topology. The trade off between democracy and rapid development is seen in the dualistic development over time. This two track route to development appears to be fading somewhat as a number of countries have been in transition towards more open economic and political systems.

\begin{tabular}{|cccc|}
\hline Primitive & Feudal & Capitalist & Social democratic \\
(slavery) & Fascist & Etatist & $\begin{array}{l}\text { Participatory } \\
\text { Economies } \\
\text {-Self-Managed } \\
\text {-Third way } \\
\text {-Just third } \\
\text {-Sustainable } \\
\text {-communist }\end{array}$ \\
\hline
\end{tabular}

Fig. 9 Topology of economic systems, focus on the future

Where is the topology headed in the future is an important question that this type of analysis can lead to. The top five countries of the HDI (Norway, Iceland, Sweden, Australia and the Netherlands) are clearly economic and political systems to which many countries aspire. People from those top five countries are probably keenly aware of some of the challenges that remain. Fig. 9 charts the path that many have suggested as the next step.

\section{References:}

Djankov, Simeon, Glaeser, Edward, La Porta, Rafael, Lopez-de-Silanes, Florencio \& Shleifer, Andrei. (2003). The new comparative economics. Journal of Comparative Economics, 31, 595-619.

Eicher, Sharon. (2004). Is Kazakhstan a market economy yet? Getting warmer. William Davidson Institute, University of Michigan, Working paper 673.

Freedom House. (2004). Freedom in the world country ratings, 1972 through 2003. Retrieved from http://www.freedomhouse. org/ratings/index. htm.

Horvat, Branko. (1982). The political economy of socialism. New York: M. E. Sharpe.

Jha Raghbendra \& K. V. Bhanu Murthy. (2003). An inverse global environmental kuznets curve. Journal of Comparative Economics, 31, 352-368.

Lange, Oskar \& Fred M. Taylor. (1964). On the economic theory of socialism. In: Benjamin Lippincott. (Ed.). New York: McGraw-Hill.

Marx, Karl. (1891). Critique of the Gotha programme. Retrieved from http://www.marxists.org/archive/marx/works/1875/gotha/.

Mondragon Cooperative Corporation. (2008). Retrieved from http://www.mondragon.mcc.es/.

Ollman, Bertell. (1976). Alienation: Marx’s conception of man in a capitalist society. Cambridge: University Press.

Robinson, Joan. (1963). Economic philosophy. Chicago: Aldine Publishing.

Slavery Today. (2008). Retrieved from http://www.iabolish.com/slavery_today.htm\#.

Smith, Adam. (1776). The wealth of nations. USA: Random House, Inc.

Socialist International. (1989, June). Declaration of principles. Stockholm: XVIII congress. Retrieved 2004 from http://www.socialistinternational.org/4Principles/dofpeng2.html\#Political.

Svejnar, Jan. (2002). Transition economies: Perfection and challenges. Journal of Economic Perspectives, 16, 3-28.

United Nations. (2003). Human development report. Oxford: Oxford University Press.

Vanek, Jaroslav. (1970). The general theory of labor managed market economies. New York: Cornell University Press.

World Bank. (2004). Poverty net. Retrieved from http://www.worldbank.org/poverty/data/index.htm\#database.

World Bank. (2004). Deininger and squire data set. Retrieved from http://www.worldbank.org/research/growth/dddeisqu.htm.

Zimbalist, Andrew, Howard J. Sherman \& Stuart Brown. (1989). Comparing economic systems. San Diego: Harcourt Brace Jovanovich. 